\title{
PENGARUH KADER TERHADAP PRAKTIK KESEHATAN IBU HAMIL PADA MASA PANDEMI COVID 19
}

\author{
Heny Rosiana ${ }^{1}$, Ana Sundari ${ }^{2}$ \\ 1,2,UPP Kampus Kendal, Poltekkes Kemenkes Semarang, Indonesia
}

\begin{abstract}
Covid 19 is caused by SARS-COVID 19 virus. The virus is spread primarily through droplets from the nose or mouth from infected person to other person in close contact. Covd 19 induce disorders on pregnancy, because of the change on physiology and immunology change on pregnancy, although its need more research to prove it. Community health workers or we called cadre is person who work in community and help midwife to give information and motivation to pregnant women to be able practice health protocol in pregnancy during pandemic. This research is quantitative quasy experiment with one group pre post design. The sample is 38 pregnant women on September to October 2020 in in Penanggulan and Pucangrejo, Pegandon, Kendal districts. The results is the role of community health worker is important and have significantly effect to pregnant women practicing health protocol in pregnancy during pandemic ( $p$ value: 0,014). Conclusion is the cadres have significantly effect to change behaviour of pregnant women practicing protocol to prevent transmission of covid 19 virus.
\end{abstract}

Keywords : Covid 19; Pregnancy; Community Health Worker 


\section{PENDAHULUAN}

Coronavirus Disease 2019 (COVID 19) merupakan penyakit menular yang disebabkan oleh Coronavirus jenis baru. Penyakit ini diawali dengan munculnya kasus pneumonia yang tidak diketahui etiologinya di Wuhan, China pada akhir Desember 2019. Kasus pertama di Indonesia terjadi pada tanggal 2 Maret 2020. (Aziz, 2020)

Covid 19 disebabkan oleh virus SARS-COVID 19 yang menyebar di antara orang-orang, terutama ketika orang yang terinfeksi melakukan kontak dekat dengan orang lain. Virus dapat menyebar dari mulut atau hodung orang yang terinfeksi dalam partikel cairan kecil ketika mereka batuk, bersin,bernyanyi atau bernafas. Orang lain dapat tertular COVID 19 ketika virus masuk ke mulut, hidung, mata yang mungkin terjadi ketika orang melakukan kontak langsung atau dekat (jarak kurang dari 1 meter) dengan orang yang terinfeksi. Virus juga dapat menyebar setelah orang yang terinfeksi bersin, batuk, atau menyentuh permukaan dan benda seperti gagang pintu dan pegangan tangan. Orang dapat terinfeksi dengan menyentuh permukaan yang terkontaminasi ini kemudian menyentuh mata, hidung, atau mulut tanpa mereka membersihkan tangan terlebih dahulu.(WHO, 2020)

Meningkatkan kesehatan ibu adalah salah satu dari tujuan pembangunan berkelanjutan atau Sustainable
Development Goals (SDG's) tentang kesehatan yang diadopsi oleh komunitas Internasional pada tahun 2015. SDG's menekaknkan pada pengurangan angka kematian ibu secara global yaitu kurang dari 70 kematian per 100.000 kelahiran hidup. (WHO, 2019)

Pada tanggal 17 Maret 2020 sudah terdapat 153 negara yang melaporkan infeksi kasus yang disebabkan oleh virus ini. COVID 19 juga menyebabkan gangguan pada ibu hamil karena perubahan fungsi fisiologis dan imunologis pada ibu hamil. Saat ini penelitian pada ibu hamil dengan COVID-19 telah menunjukkan beberapa komplikasi maternal dan neonatal, tetapi bukti penelitian yang lebih banyak masih dibutuhkan. Penyakit respirasi selama kehamilan merupakan maslaah yang dapat mempengaruhi covid 19 dan membutuhkan perawatan medis. (Omer et al., 2020)

Tindakan pencegahan, termasuk sering mencuci tangan, menahan diri dari aktivitas luar ruangan yag berlebihan kecuali dalam keadaan darurat, menghindari individu yang terinfeksi, tempat keramaian dan pertemuan umum, harus diikuti secara ketat oleh ibu hamil. Mengelola COVID 19 pada kehamilan untuk penatalaksanaan efektif pada ibu hamil yang dicurigai COVID 19 harus diisolasi dan dipindahkan ke rumah sakit yang dilengkapi dengan fasilitas kesehatan yang memadai dan dokter terlatih untuk merawat pasien yang 
mengalami penyakit kritis ini. (Omer et al 2020)

Pelayanan kesehatan ibu hamil, bersalin, nifas dan bayi baru lahir di masa pandemi ini diselenggarakan dengan mempertimbangkan pencegahan penularan virus corona baik bagi ibu, bayi maupun tenaga kesehatan. Pembatasan kunjungan pemeriksaan Antenatal Care (ANC) dan Postnatal care (PNC) diimbangi dengan telekomunikasi antara tenaga kesehatan dan ibu secara perorangan maupun menyelenggarakan kelas ibu secara perorangan maupun dengan menyelenggarakan kelas ibu secara online. Salah satu permasalahan yang timbul dari pandemi ini adalah pengetahuan ibu dan keluarga terkait COVID 19 dan pelayanan kesehatan bagi ibu dan bayi baru lahir di era pandemi. (Kemenkes, 2020)

Pelayanan kesehatan pada ibu perlu dimodifikasi karena akses dan ketersediaan layanan essensial mengalami pergeseran selama wabah COVID-19. Praktik - praktik perawatan mandiri dan keluarga perlu terus didukung dalam menyokong layanan kesehatan berbasiskomunitas salah satunya adalah menggandeng kader kesehatan untuk mendukung Ante Natal Care (ANC) dasar. Pelayanan kesehatan berbasis komunitas, termasuk penjangkauan dan kampanye, dalam konteks pandemi COVID- 19. (WHO, 2020)
Peran kader sangat besar karena selain sebagai pemberi informasi kesehatan kepada masyarakat juga sebagai penggerak masyarakat dan melaksanakan perilaku hidup bersih dan sehat.(Kemenkes RI, 2019)

\section{METODOLOGI PENELITIAN}

Rancangan desain yang digunakan dalam penelitian adalah penelitian kuantitatif quasi experiment dengan pendekatan one group pre - post design. Penelitian dilakukan di desa Pucangrejo dan Desa Penanggulan Kecamatan Pegandon Kabupaten Kendal pada 38 sampel ibu hamil pada tanggal Septemer 2020 sampai Oktober 2020. Uji analisis yang digunakan dalam penelitian ini yaitu Paired T simple Test.

\section{HASIL PENELITIAN DAN BAHASAN}

Kader kesehatan merupakan warga masyarakat yang dipilih masyarakat oleh masyarakat serta bekerja dengan sukarela untuk membantu peningkatan kesehatan masuyarakat termasuk berupaya dalam mendukung pencegahan kejadian di masyarakat. (Kemenkes RI., 2019)

Peran kader dalam pemberdayaan masyarakat adalah sebagai penggerak masyarakat, pemberi promosi kesehatan pada masyarakat sehingga masyarakat mampu merubah perilaku kesehatannya. Kader berperan penting sebagai pemberi informasi kepada masyarakat sehingga kader berperan dalam peningkatan 
kualitas hidup masyarakat terutama dalam penerapan pola hidup bersih dan sehat yang akan berdampak pada peningkatan kualitas hidup ibu hamil.

Tabel 1. Praktik Pencegahan Covid 19 Pada Ibu Hamil

\begin{tabular}{llllll}
\hline Praktik & $\begin{array}{l}\text { Rata- } \\
\text { rata } \\
\text { nilai }\end{array}$ & SD & $\begin{array}{l}\text { Nilai } \\
\text { Maks }\end{array}$ & $\begin{array}{l}\text { Nilai } \\
\text { Min }\end{array}$ & $\begin{array}{l}\text { Value } \\
\text { Value }\end{array}$ \\
\hline $\begin{array}{l}\text { Pre test- } \\
\text { post test }\end{array}$ & 84 & 2.02 & 177 & 1,50 & 0,014 \\
\hline
\end{tabular}

Praktik ibu hamil dalam pencegahan Covid 19 mengalami kenaikan dari pre test dan post test. Hal ini dilihat dari $p$ value yaitu 0,014 . Peran kader sebagai motivator dan pemberi informasi tentang cara pencegahan penularan Covid 19 memberikan pengaruh dalam peningkatan praktik ibu hamil mencegah covid 19 pada dirinya.

Pemakaian masker selama ibu hamil, mencuci tangan 20 detik, mengkonsumsi makanan bergizi seimbang, minum tablet $\mathrm{Fe}$, dan janji temu dengan bidan untuk periksa hamil dilakukan dengan baik oleh ibu hamil.

Pemakaian masker menjadi hal penting selama covid 19. Pemakaian masker menutupi hidung dan mulut untuk mencegah penularan virus covid 19 . Penggunaan masker mempunyai kelebihan tersendiri dan efek perlindungan yang tak terbantahkan terhadap infeksi. Namun ada beberapa kemungkinan terjadi perasaan subjektif yaitu merasa tidak nyaman saat pemakaian terutama pada saat aktivitas fisik. (Matuschek et al., 2020)

Aktivitas fisik selama hamil pada masa pandemic dapat mengurangi kecemasan dan panic. Pada penelitian yang dilakukan Tom Farrel et al bahwa aktivitas fisik mamu mengurangi kecemasan dan depresi pada masa pandemi. (Farrell et al., 2020)

Antenatal care pada masa pandemi covid mengalami perubahan dalam pelayanannya. Ibu hamil mengurangi pemeriksaannya di layanan kesehatan dan menggunakan komunikasi dengan bidan untuk mengetahui perkembangan kesehatan ibu dan janinnya. (Muhaidat $\mathrm{N}$, Fram K, Thekrallah F, Qatawneh A, 2020)

Pada masa pandemik covid ini kita harus meningkatkan system kekebalan tubuh yang merupakan kekuatan pertahanan tubuh melawan bakteri, virus dan organisme penyebab penyakit yang mungkin kita sentuh, konsumsi dan hirup setiap hari.

Mencuci tangan dengan sabun adalah salah satu tindakan sanitasi dengan membersihkan tangan dan jari jemari menggunakan air dan sabun oleh manusia untuk menjadi bersih dan memutuskan mata rantai kuman (Suryani \& Sodik, 2018)

Hal-hal yang dapat meningkatkan daya tahan tubuh yaitu makan makanan bergizi seimbang. Konsumsi makanan dengan gizi seimbang dan aman dapat meningkatkan system kekebalan tubuh 
dan menurunkan risiko penyakit kronis dan penyakit infeksi.

Perbanyak konsumsi buah seperti pisang, jeruk, alpukat, nanas, apel, papaya, manggis dll. Sayuran yang kaya serat dapat menjaga kekebalan tubuh kita, sayuran berdaun hijau, terong, tauge, daun singkong, labu dan lain-lain. Kecukupan gizi terutama vitamindan mineral sangat diperlukan dalam mempertahankan system kekebalan tubuh yang optimal, sayuran dan buah-buahan merupakan sumber terbaik berbagai vitamin, mineral dan serat. (Kemenkes, 2020)

Ibu hamil merupakan kelompok rentan yang memiliki risiko tinggi mengalami anemia. Hal itu disebabkan adanya peningkatan volume darah selama kehamilan untuk pembentukan plasenta, janin dan cadangan zat besi dalam ASI. Anemia akan menurunkan daya tahan tubuh sehingga rentan terhadap berbagai infeksi, termasuk infeksi COVID-19 dan penyakit yang ditimbulkannya. Selain itu, anemia pada ibu hamil akan meningkatkan bayi berat lahir rendah yang tentunya akan meningkatkan risiko terjadinya stunting. Pencegahan anemia gizi pada ibu hamil dilakukan dengan memberikan minimal 90 Tablet Tambah Darah (TTD) selama kehamilan dan dimulai sedini mungkin. Pemberian TTD setiap hari selama kehamilan dapat menurunkan risiko anemia maternal $70 \%$ dan defisiensi besi 57\%. Sedangkan untuk pengobatan anemia mengacu pada
Pedoman Penatalaksanaan Pemberian Tablet Tambah Darah. (Kemenkes RI, 2020)

\section{KESIMPULAN}

Kader memiliki pengaruh terhadap perubahan praktik pencegahan penularan Covid 19 pada ibu hamil. Kader memberikan informasi dan motivasi pada ibu hamil untuk cuci tangan dengan teratur selama 20-40 detik, memakai masker dengan benar, mengonsumsi makanan yang bergizi seimbang, mengonsumsi tablet Fe dan melakukan janji temu untuk ANC dengan tenaga kesehatan.

\section{DAFTAR PUSTAKA}

1. Aziz, M. A. (2020). Rekomendasi Penanganan Infeksi Virus Corona (Covid-19) Pada Maternal (Hamil, Bersalin Dan Nifas). Penanganan Infeksi Virus Corona Pada Maternal, 1(3), 9-11. https://pogi.or.id/publish/rekomendasipenanganan-infeksi-virus-coronacovid-19-pada-maternal/

2. Farrell, T., Reagu, S., Mohan, S., Elmidany, R., Qaddoura, F., Ahmed, E., Corbett, G., Lindow, S., Abuyaqoub, S., \& Alabdulla, M. (2020). The Impact of the COVID-19 Pandemic on the Perinatal Mental Health of Women. Journal of Perinatal Medicine. https://doi.org/10.1515/jpm2020-0415

3. Kemenkes. (2020). Final-PanduanGizi-Seimbang-Pada-Masa-Covid-191.Pdf. In Panduan Gizi Seimbang Pada Masa Pandemi COVID-19 (p. 31).

4. Kemenkes RI. (2019). Panduan Orientasi Kader Posyandu. In Kemenkes RI (Vol. 53, Issue 9).

5. Kemenkes RI. (2020). Pedoman pelayanan gizi covid19. 
6. Matuschek, C., Moll, F., Fangerau, H., Fischer, J. C., Zänker, K., van Griensven, M., Schneider, M., Kindgen-Milles, D., Knoefel, W. T., Lichtenberg, A., Tamaskovics, B., Djiepmo-Njanang, F. J., Budach, W., Corradini, S., Häussinger, D., Feldt, T., Jensen, B., Pelka, R., Orth, K., ... Haussmann, J. (2020). Face masks: benefits and risks during the COVID19 crisis. European Journal of Medical Research, 25(1), 32. https://doi.org/10.1186/s40001-02000430-5

7. Muhaidat $\mathrm{N}$, Fram $\mathrm{K}$, Thekrallah $\mathrm{F}$, Qatawneh A, A.-B. A. (2020). Pregnancy During COVID-19 Outbreak: The Impact of Lockdown in a Middle-Income Country on Antenatal Healthcare and Wellbeing. Int J Womens Health, 2020;12:10. https://doi.org/https://doi.org/10.2147// JWH.S280342

8. Omer, S., Ali, S., \& Babar, Z. U. D. (2020). Preventive measures and management of COVID-19 in pregnancy. Drugs \& Therapy Perspectives: For Rational Drug Selection and Use, 1-4. https://doi.org/10.1007/s40267-02000725-x

9. Suryani, S. I., \& Sodik, M. A. (2018). Perilaku Cuci Tangan Pakai Sabun. https://doi.org/10.31227/osf.io/g3fw2

10. WHO. (2019). World Health statistics 2019. Monitoring Health for the SDG's. In WHO.

11. WHO. (2020). Panduan interim. 